\title{
Polyphasic Evidence for the Transfer of Rhodococcus roseus to Rhodococcus rhodochrous
}

\author{
FREDERICK A. RAINEY, JUTTA BURGHARDT, REINER KROPPENSTEDT, \\ STEPHAN KLATTE, AND ERKO STACKEBRANDT* \\ German Collection of Microorganisms and Cell Cultures $\mathrm{GmbH}$, \\ 38124 Braunschweig, Germany
}

\begin{abstract}
Investigation of fatty acid and mycolic acid properties of certain members of the genera Nocardia and Rhodococcus indicated identical spectra for certain pairs of organisms. Binary $16 S$ rDNA sequence homology for the pairs Rhodococcus rhodochrous and $R$. roseus, Nocardia calcarea and $R$. erythropolis, and $N$. restricta and $R$. equi ranged between 99.2 and $99.9 \%$ for each of these pairs of species. Corresponding DNA-DNA similarity values, obtained by the spectrophotometric method, were significantly higher than $70 \%$. Because certain chemotaxonomic properties and the majority of published phenotypic characters support the high degree of relatedness, we propose to transfer $R$. roseus to $R$. rhodochrous. The transfer of $N$. calcarea to $R$. erythropolis, and the transfer of Nocardia restricta to Rhodococcus equi (M. Goodfellow, p. 1472-1481, in P. H. A. Sneath et al., ed., Bergey's Manual of Systematic Bacteriology, vol. 2, 1986) is confirmed.
\end{abstract}

The unambiguous assignment of actinomycete species to the genera Rhodococcus and Nocardia constitutes a problem, because virtually no single characteristic of diagnostic value, such as phage susceptibility (19), cell wall chemistry, fatty acid and phospholipid composition, overall size of mycolic acids, and DNA G + C content, has been found to clearly distinguish between members of the two genera (6). Today, the morphological life cycle and the presence of a cyclic menaquinone of the MK- $8\left(\mathbf{H}_{4}\right)$ type $(1,9,15)$ are the main features that distinguish members of Nocardia from those of Rhodococcus. Recent applications of $16 \mathrm{~S}$ rDNA sequence analysis, DNA hybridization, and chemotaxonomic analysis to strains of both genera have led to taxonomic rearrangements that excluded certain species from the genus Rhodococcus $(2,8,13,21,23)$ or showed them to be synonyms (12). In this communication we present further evidence that the present classification of certain additional Nocardia and Rhodococcus species is not supported by their phylogenetic and phenotypic relationships.

\section{MATERIALS AND METHODS}

Bacterial strains and cultivation. The following strains were investigated for fatty acid and mycolic acid pattern analysis, DNA reassociation, and 16S rDNA analysis (16S rDNA accession numbers in brackets): Nocardia restricta DSM $43199^{\mathrm{T}}$ (X80613), Rhodococcus rhodochrous DSM 43241 ${ }^{\mathrm{T}}$ (X79288), $R$. equi DSM $20307^{\mathrm{T}}$ (X80614), $R$ erythropolis DSM $43066^{\mathrm{T}}$ (X79289), $R$. roseus DSM $43274^{\mathrm{T}}$ (X80624), and $R$ ruber DSM $43338^{\mathrm{T}}$ (X80625). Strains were grown on TSB agar (3\% [wt/vol] Trypticase soy broth [BBL], 1.5\% [wt/vol] Bacto Agar [Difco]) for 4 days at $28^{\circ} \mathrm{C}$. For DNA hybridization experiments, strains were grown in Trypticase soy broth for 4 days at $28^{\circ} \mathrm{C}$ on a rotary shaker, checked for purity, inactivated by the addition of $1 \%$ ( $\mathrm{vol} / \mathrm{vol}$ ) formaldehyde, harvested by centrifugation, and washed twice with distilled water.

16S rDNA sequencing. Extraction of genomic DNA and amplification of the 16S rDNA were performed as described previously (20). PCR products were sequenced directly with a Taq DyeDeoxy Terminator Cycle Sequencing Kit (Applied Biosystems) as specified by the manufacturer. The sequence reactions were electrophoresed in an Applied Biosystems 373A DNA Sequencer. New sequences were manually aligned with published sequences from Corynebacte-

\footnotetext{
* Corresponding author. Mailing address: German Collection of Microorganisms and Cell Cultures $\mathrm{GmbH}$, Mascheroder Weg $1 \mathrm{~b}$, 38124 Braunschweig, Germany. Phone: 49531 2616 352. Fax: 49531 2616 418. Electronic mail address: stackebrandt@venus.gbf-braunschweig.d400.de.
}

rium, Mycobacterium, Gordona, Rhodococcus, and Nocardia species included in the Ribosome Database Project (17) and from our own entries. Direct pairwise sequence homologies were calculated and are presented as percentage similarity values.

DNA isolation and characterization. DNA isolation and DNA-DNA hybridization $(4,10)$ and determination of renaturation rates $(3,11)$ were performed by previously described methods.

Lipid and mycolic acid analysis. Whole-cell fatty acids and free mycolic acids were analyzed as described previously $(8,14,18)$.

\section{RESULTS AND DISCUSSION}

$16 \mathrm{~S}$ rDNA analysis of certain pairs of type strains of Nocardia and Rhodococcus species yielded almost identical results (Table 1). Even at this high level of sequence homology, DNA reassociation values may drop below the level of $70 \%$ similarity recommended for identification of separate species (25); therefore, DNA hybridization was carried out for these pairs of strains. In each case, values ranged above $78 \%$ (Table 1), which can be taken as clear evidence that these strains should be united as a single species. The differentiation of authentic Rhodococcus species by the DNA reassociation approach is possible as demonstrated by the binary value of 39 and $44 \%$ for the pair $R$. rhodochrous and $R$. ruber and the pair $R$. roseus and $R$. ruber, respectively. The corresponding $16 \mathrm{~S}$ rDNA homology values are about $2.5 \%$ lower than those observed between pairs of organisms considered

TABLE 1. Comparison of binary 16S rDNA homology values and DNA reassociation values and taxonomic conclusion based on the genotypic and phenotypic characterization of the strains

\begin{tabular}{|c|c|c|c|}
\hline Pair of organisms & $\begin{array}{l}\text { 16S rDNA } \\
\text { homology } \\
(\%)\end{array}$ & $\begin{array}{c}\text { DNA } \\
\text { reassociation } \\
\text { values }(\%)\end{array}$ & $\begin{array}{c}\text { Taxonomic } \\
\text { conclusion based } \\
\text { on priority }\end{array}$ \\
\hline$N$. calcarea, $R$. erythropolis & 99.5 & 93 & R. erythropolis \\
\hline N. restricta, $R$. equi & 99.9 & 96 & R. equi \\
\hline$R$. rhodochrous, $R$. roseus & 99.2 & $78,82^{a}$ & R. rhodochrous \\
\hline R. rhodochrous, $R$. ruber & 97.5 & 39 & $\mathrm{NC}^{b}$ \\
\hline$R$. roseus, $R$. ruber & 97.4 & 44 & $\mathrm{NC}$ \\
\hline
\end{tabular}

${ }^{a}$ Two independent determinations.

${ }^{b} \mathrm{NC}$, no charge. 
TABLE 2. Comparison of mycolic acid chain length and principal menaquinone of closely related Nocardia and Rhodococcus species

\begin{tabular}{|c|c|c|c|}
\hline DSM no. & Name & $\begin{array}{l}\text { Mycolic acid } \\
\text { chain length }\end{array}$ & $\begin{array}{l}\text { Principal } \\
\text { menquinone }\end{array}$ \\
\hline DSM $43757^{\mathrm{T}}$ & N. asteroides & $\mathrm{C}_{53}-\mathrm{C}_{59}$ & MK-8 $\left(\mathrm{H}_{4 \mathrm{cycl}}\right)$ \\
\hline DSM $43199^{\mathrm{T}}$ & N. restricta & $\mathrm{C}_{30}-\mathrm{C}_{36}$ & MK-8 $\left(\mathrm{H}_{2}\right)$ \\
\hline DSM $20307^{\mathrm{T}}$ & R. equi & $\mathrm{C}_{30}-\mathrm{C}_{36}$ & MK-8 $\left(\mathrm{H}_{2}\right)$ \\
\hline DSM $43188^{\mathrm{T}}$ & N. calcarea & $\mathrm{C}_{34}-\mathrm{C}_{40}$ & MK-8 $\left(\mathrm{H}_{2}\right)$ \\
\hline DSM $43066^{T}$ & R. erythropolis & $\mathrm{C}_{34}-\mathrm{C}_{40}$ & MK-8 $\left(\mathrm{H}_{2}\right)$ \\
\hline DSM $43241^{\mathrm{T}}$ & R. rhodochrous & $\mathrm{C}_{38}-\mathrm{C}_{46}$ & MK-8 $\left(\mathrm{H}_{2}\right)$ \\
\hline DSM $43274^{\mathrm{T}}$ & $R$. roseus & $\mathrm{C}_{38}-\mathrm{C}_{46}$ & MS-8 $\left(\mathrm{H}_{2}\right)$ \\
\hline DSM $43338^{T}$ & R. ruber & $\mathrm{C}_{42}-\mathrm{C}_{48}$ & MK-8 $\left(\mathrm{H}_{2}\right)$ \\
\hline
\end{tabular}

${ }^{a}$ Number of carbon atoms in mycolic acid.

to belong to the same species (Table 1). In addition, results of chemotaxonomic analysis of mycolic acids (Table 2), principal menaquinones (Table 2), and fatty acids (Table 3) agree with the conclusions of the genotypic analyses. Pairs of genomically highly related organisms exhibited identical chain length of mycolic acids and almost identical fatty acid spectra. The close overall similarity between the pair $N$. calcarea and $R$. erythropolis and between the pair $N$. restricta and $R$. equi has already been reported by Goodfellow (5), who described $N$. calcarea and $N$. restricta as synonyms of $R$. erythropolis and $R$. equi, respectively. Results of phylogenetic and additional chemotaxonomic studies fully confirm these conclusions.

Thus, on the basis of rule 42 of the International Code of Nomenclature of Bacteria (16), according to which the oldest legitimate epithet must be retained following the union of taxa of equal rank, we propose to transfer as synonyms Rhodococcus roseus to Rhodococcus rhodochrous.

The species $R$. roseus (24) was revived for two strains of a taxon that was not included in the 1980 edition of the $A p$ proved Lists of Bacterial Names (22). The justification for the distinct status of $R$. roseus was based on a numerical phenetic analysis. Its relatedness to $R$. rhodochrous (7) was mentioned, but differences between the two taxa in the number of double bonds in mycolic acids and in certain pheno- typic characteristics, such as resistance to $250 \mu \mathrm{g}$ of $\mathrm{NH}_{2} \mathrm{OH}$. $\mathrm{HCl}$ per $\mathrm{ml}$, tolerance to $1 \%$ Tween 80 , presence of acetamidase, utilization of mannitol as a carbon source, and use of nicotinamide as a nitrogen source, were believed to justify the description of a new species. DNA reassociation values of about $80 \%$ indeed indicate that certain genomic and hence certain phenotypic differences are expected to exist between the type strains of the two species. However, we consider the physiological differences not to be significant, especially as only two strains of $R$. roseus had been included in the numerical phenetic analysis and the possible influence of plasmidencoded physiological characteristics has not been investigated.

The following is an emended description of $R$. rhodochrous, based on the descriptions of $R$. rhodochrous (5) and $R$. roseus (24) and data presented in this study. Because Tsukamura et al. (24) provide comparative data on strains of both species, the emendation is based mainly on their study. Only properties that show either 0 to $100 \%$ positive reactions are listed. Reactions in which strains of the species differ are listed in reference 24 .

Slightly acid-fast rods. Some strains undergo an elementary branching-rod-coccus growth cycle. Temporary mycelium may be formed. Rough, orange or pinkish to red colonies are formed in egg media, on Saunton's agar, and on modified Saunton's agar medium (glutamate substituted for asparagine). Growth occurs at 28 and $40^{\circ} \mathrm{C}$ but not at $45^{\circ} \mathrm{C}$.

Resistant to hydroxylamine hydrochloride $(500 \mu \mathrm{g} / \mathrm{ml})$ and para-nitrobenzoic acid $(0.5 \mathrm{mg} / \mathrm{ml})$; most strains are resistant to ethambutol $(5 \mu \mathrm{g} / \mathrm{ml})$. Tolerant to $0.1 \%$ salicylate and $0.2 \%$ picric acid; most strains are tolerant to $0.2 \%$ nitrite. Sensitive to rifampin $(25 \mu \mathrm{g} / \mathrm{ml})$.

Allantoinase and nicotinamidase negative. $\alpha$-Esterase, $\beta$-esterase, and $\beta$-galactosidase negative. Nitrate is reduced to nitrite.

Glutamate is used as an $\mathrm{N}$ and $\mathrm{C}$ source, but benzamide and monoethanolamine are not. Glucose, sucrose, mannitol, ethanol, glucitol, $n$-propanol, and $n$-butanol are used as sole sources of carbon, but arabinose, galactose, inositol, and rhamnose are not.

Isolated from soil.

The mol\% $\mathrm{G}+\mathrm{C}$ of the DNA is 67 to $70\left(T_{m}\right)$.

Type strain: DSM 43241 (ATCC 13808).

TABLE 3. Comparison of fatty acid profiles of closely related Nocardia and Rhodococcus species

\begin{tabular}{|c|c|c|c|c|c|c|c|c|c|c|c|c|c|c|}
\hline \multirow[b]{2}{*}{ DSM no. } & \multirow[b]{2}{*}{ Name } & \multicolumn{13}{|c|}{ Fatty acid content ( $\%$ of total fatty acids methyl esters) ${ }^{a}$} \\
\hline & & 14:0 & $15: 0$ & $\begin{array}{l}16: 1 \\
\text { cis } 9\end{array}$ & $\begin{array}{c}16: 1 \\
\text { cis } 10\end{array}$ & $16: 0$ & $\begin{array}{r}16: 0 \\
10 \mathrm{Me}\end{array}$ & $\begin{array}{l}17: 1 \\
\text { cis } 9\end{array}$ & 17:0 & $\begin{array}{r}17: 0 \\
10 \mathrm{Me}\end{array}$ & $\begin{array}{l}18: 1 \\
\text { cis } 9\end{array}$ & 18:0 & $\begin{array}{r}18: 0 \\
10 \mathrm{Me}\end{array}$ & $\begin{array}{l}19: 1 \\
\text { cis } 9\end{array}$ \\
\hline DSM $43757^{\mathrm{T}}$ & N. asteroides & 1 & 1 & 5 & 15 & 22 & & 2 & 6 & & 17 & 4 & 27 & \\
\hline DSM $43199^{T}$ & N. restricta & 8 & 3 & 5 & 12 & 25 & 4 & 3 & 3 & 2 & 13 & 1 & 17 & 1 \\
\hline DSM $20307^{\mathrm{T}}$ & R. equi & 10 & 2 & 6 & 14 & 30 & 7 & 2 & 2 & 2 & 8 & 1 & 12 & 2 \\
\hline DSM $43188^{\mathrm{T}}$ & N. calcarea & 5 & 4 & 3 & 17 & 27 & 1 & 3 & 3 & 5 & 12 & 1 & 16 & 2 \\
\hline DSM $43066^{\mathrm{T}}$ & R. erythropolis & 6 & 5 & 2 & 15 & 25 & 3 & 3 & 2 & 4 & 10 & & 18 & \\
\hline $\operatorname{DSM} 43241^{\mathrm{T}}$ & R. rhodochrous & 2 & 1 & 6 & 18 & 29 & 7 & 1 & 1 & 2 & 8 & 1 & 22 & \\
\hline DSM $43274^{T}$ & R. roseus & 1 & 2 & 4 & 15 & 30 & 8 & 1 & & 3 & 6 & & 24 & 3 \\
\hline DSM $43338^{\mathrm{T}}$ & R. ruber & 2 & 4 & 2 & 20 & 25 & 2 & 4 & 3 & 3 & 16 & 1 & 18 & 1 \\
\hline
\end{tabular}

${ }^{a}$ Examples for abbreviations: 14:0, straight-chain tetradecanoic acid; 18:1 cis9, monounsaturated octadecenoic acid (oleic acid); 18:0 10Me, 10-methyloctadecanoic acid (tuberculostearic acid). 


\section{REFERENCES}

1. Collins, M. D, O. W. Howarth, E. Grund, and R. M. Kroppenstedt. 1987. Isolation and structural determination of some new minor metraquinones from Nocardia brasiliensis. FEMS Microbiol. Lett. 41:35-39.

2. Collins, M. D., J. Smida, M. Dorsch, and E. Stackebrandt. 1988. Tsukumurella gen. nov. harboring Conynebacterium paurometabolum and Rhodococcus aurantiacus. Int. J. Syst. Bacteriol. 38:385-391.

3. De Ley, J., H. Cattoir, and A. Reynaerts. 1970. The quantitative measurement of DNA hybridisation from renaturation rates. Eur. J. Biochem. $12: 133-142$.

4. Escara, J. F., and J. R. Hutton. 1980. Thermal stability and renaturation of DNA in dimethylsulphoxide solutions: acceleration of renaturation rate. Biopolymers 19:1315-1327.

5. Goodfellow, M. 1986. Genus Rhodococcus, p. 1472-1481. In P. H. A. Sneath, N. S. Mair, M. E. Sharpe, and J. G. Holt (ed.), Bergey's manual of systematic bacteriology., vol. 2. The Williams \& Wilkins Co., Baltimore.

6. Goodfellow, M. 1992. The family Nocardiaceae, p. 1188-1213. In A. Balows, H. G. Trüper, M. Dworkin, W. Harder, and K. H. Schleifer (ed.), The procaryotes, 2nd ed. Springer-Verlag, New York

7. Goodfellow, M., and G. Alderson. 1977. The actinomycete genus Rhodococcus: a home for the 'rhodochrous' complex. J. Gen. Microbiol. 100:99-122.

8. Häggblom, M. M., L. J. Liesa, N. Nohynek, N. J. Palleroni, K. Kronqvist, E.-L. Nurmiaho-Lassila, M. S. Salkinoja-Salonen, S. Klatte, and R. M. Kroppenstedt. 1994. Transfer of polychlorophenol-degrading Rhodococcus chlorophenolicus (Apajalahti ct al. 1986) to the genus Mycobacterium as Mycobacterium chlorophenoficum comb. nov. Int. J. Syst. Bacteriol. 44:485493.

9. Howarth, O. W., E. Grund, R. M. Kroppenstedt, and M. D. Collins. 1986. Structural determination of a new naturally occurring cyclic vitamin $\mathbf{K}$. Biochem. Biophys. Res. Commun. 140:916-923.

10. Huss, V. A. R., H. Festl, and K.-H. Schleifer. 1983. Studies on the spectrophotometric determination of DNA hybridization from renaturation rates. Syst. Appl. Microbiol. 4:184-192.

11. Jahnke, K.-D. 1992. BASIC computer program for evaluation of spectroscopic DNA renaturation data from GILFORD SYSTEM 2600 spectrophotometer on a PC/XT/AT type personal computer. J. Microbiol. Methods 15:61-73.

12. Klatte, S., K.-D. Jahnke, R. M. Kroppenstedt, F. Rainey, and E. Stackebrandt. 1994. Rhodococcus luteus a later subjective synonym of Rhodococcus fascians. Int. J. Syst. Bacteriol. 44:627-630.

13. Klatte, S., F. A. Rainey, and R. M. Kroppenstedt. 1994. Transfcr of Rhodococcus aichiensis Tsukamura 1982 and Nocardia amarae Lechevalier and Lechevalier 1974 to the genus Gordona as Gordona aichiensis comb. nov. and Gordona amarae comb. nov. Int. J. Syst. Bacteriol. 44:769-773.

14. Kroppenstedt, R. M. 1985. Fatty acid and menaquinone analysis of actinomycetes and related organisms, p. 173-199. In M. Goodfellow and D. E. Minnikin (ed.), Chemical methods in bacterial systematics. Academic Press, Ltd., London.

15. Kroppenstedt, R. M. 1987. Chemische Untersuchungen an Actinomycetalcs und verwandten Taxa, Korrelation von Chemosystematik und Phylogenie. Habilitationsschrift, Technische Ilochschule Darmstadt, Darmstadt, Germany.

16. Lapage, S. P., P. H. A. Sneath, E. F. Lessel, V. B. D. Skerman, H. P. R. Seeliger, and W. A. Clark (ed.). 1992. International code of nomenclature of bacteria. 1990 revision. American Society for Microbiology, Washington, D.C.

17. Larsen, N., G. J. Olsen, B. L. Maidak, M. J. McCaughey, R. Overbeek, T. J. Macke, T. L. Marsh, and C. R. Woese. 1993. The ribosomal database project. Nucleic Acids Res. 21:3021-3023.

18. Miller, $\mathrm{L}_{\text {, }}$ and T. Berger. Bacterial identification by gas chromatography of whole cell fatty acids. Gas chromatography, applications note 228-41. Hewlett-Packard Co., Avondale, Pa.

19. Prauser, H. 1984. Phage host ranges in the classification and identification of Gram-positive branched and related bacteria, p. 617-633, In L. Ortiz-Ortiz, L. F. Bojalil, and V. Yakoleff (ed.), Biological, biochemical and biomedical aspects of actinomycetes. Academic Press, Inc., Orlando, Fla.

20. Rainey, F. A., M. Dorsch, H. W. Morgan, and E. Stackebrandt. 1992. $16 \mathrm{~S}$ IDNA analysis of Spirochaeta thermophila: its phylogenetic position and implications for the systematics of the order Spirochaetales. Syst. Appl. Microbiol. 15:197-202.

21. Rainey, F. A., S. Klatte, R. M. Kroppenstedt, and E. Stackebrandt. 1995 Dietzia, a new genus including Dietzia maris comb. nov., formerly Rhodococcus maris. Int. J. Syst. Bacteriol, 45:32-36.

22. Skerman, V. B. D., V. McGowan, and P. H. A. Sneath. 1980. Approved list of bacterial names. Int. J. Syst. Bacteriol. 30:225-420.

23. Stackebrandt, E., J. Smida, and M. D. Collins. 1988. Evidence of phylogenetic heterogeneity within the genus Rhodococcus: revival of the genus Gordona (Tsukamura). J. Gen. Appl. Microbiol. 34:341-348.

24. Tsukamura, M., I. Yano, T. Kudo, and A. Miyama. 1991. Rhodococcus roseus sp. nov., nom. rev. Int. J. Syst. Bacteriol. 41:385-389.

25. Wayne, L. G., D. J. Brenner, R. R, Colwell, P. A. D. Grimont, O. Kandler, M. I. Krichevsky, L. H. Moore, W. E. C. Moore, R. G. E. Murray, E Stackebrandt, M. P. Starr, and H. G. Trüper. 1987. Report of the ad hoc committee on reconciliation of approaches to bacterial systematics. Int. J. Syst. Bacteriol. 37:463-464. 